\title{
Penggolongan Penduduk Dalam Pembuatan Surat Keterangan Waris Terkait Pendaftaran Hak Atas Tanah Setelah Berlakunya Undang-Undang Nomor 12 Tahun 2006 Tentang Kewarganegaraan Republik Indonesia
}

\author{
Ni Ketut Novita Sari, Sihabudin, Bambang Sutjito, \\ Program Studi Magister Kenotariatan \\ Fakultas Hukum Universitas Brawijaya Malang \\ sarinovita12@yahoo.com
}

\begin{abstract}
This research aims at analyzing the classification of citizen in the making of statement of inheritance related to the registration of right over land after the enactment of Law number 12 year 2006 about the Republic of Indonesia citizenship. It also analyzes the legal force of statement of inheritance issued by notary, statement of inheritance issued by Village chief of the head of the district, and the statement of inheritance issued by Balai Harta Peninggalan (the office of inheritance affairs) related to the registration of right over land after the enactment of Law number 12 year 2006. This research is normative using statute, conceptual, and historical approaches. Data analysis employed Grammatical and historical interpretations The findings of the study show that citizen classification in the making of statement of inheritance still applies as the regulation has not yet been repealed. Regulation for specific group of citizen should not imperatively apply. Whwn the rule is repealed, the regulation becomes alternative of facultative for the citizens of Indonesia. The legal force of statement of inheritance couses problems because the regulation regarding the form of the document is no clear so that it does not qualify to be a perfect evidence.
\end{abstract}

Keywords: Citizen Classification, Land Registry, Statement of Inheritance.

\begin{abstract}
Abstrak
Penelitian ini bertujuan menganalisis penggolongan penduduk dalam pembuatan Surat Keterangan Waris terkait pendaftaran hak atas tanah setelah berlakunya Undang-Undang Nomor 12 Tahun 2006 Tentang Kewarganegaraan. Selain itu juga menganalisis kekuatan hukum akta keterangan hak mewaris yang dibuat oleh Notaris, Surat Keterangan Ahli waris yang dibuat oleh ahli waris dan dikuatkan oleh Kepala Desa/Kelurahan dan Camat, dan Surat Keterangan Waris yang dibuat oleh Balai Harta Peninggalan terkait pendaftaran hak atas tanah setelah berlakunya Undang-Undang Nomor 12 Tahun 2006. Jenis penelitian ini adalah penelitian yuridis normative dengan menggunakan pendekatan perundang-undangan (statute approach), pendekatan konsep (conceptual approach) dan pendekatan historis (historical approach). Pengolahan data menggunakan interpretasi gramatikal dan interpretasi historis. Hasil penelitian, bahwa penggolongan penduduk dalam pembuatan surat keterangan waris masih terjadi karena politik hukum pemerintahan Kolonial Belanda, serta keberlakuan asas konkordansi untuk mengisi kekosongan hukum (rechtvacuum) sesuai Pasal II aturan Peralihan Undang-Undang Dasar 1945. Kekuatan hukum surat keterangan waris sebagai suatu alat bukti perdata memiliki perbedaan sesuai dengan bentuknya masing-masing, sehingga yang paling tepat untuk digunakan setelah berlakunya Undang-Undang Nomor 12 Tahun 2006 adalah akta otentik yang dibuat oleh Notaris, karena memiliki kekuatan pembuktian yang sempurna. Serta dasar hukum notaris membuatnya sebagai dasar kewenangan jelas dan sesuai dengan kepastian hukum.
\end{abstract}

Kata Kunci: Penggolongan penduduk, Pendaftaran Tanah, Surat Keterangan Waris. 


\section{Pendahuluan}

Kepastian hukum merupakan salah satu tujuan dari Peraturan Dasar PokokPokok Agraria (UUPA) yang termuat dalam Pasal 19 ayat (1) yang menyataan bahwa "dengan demikian bahwa Pemerintah mempunyai kewajiban untuk melaksanakan pendaftaran tanah diseluruh wilayah Republik Indonesia”. Kemudian ditegaskan dengan dikeluarkannya Peraturan Pemerintah Nomor 24 Tahun 1997 tentang Pendaftaran Tanah sebagai penyempurna Peraturan sebelumnya yakni Peraturan Pemerintah Nomor 10 Tahun 1961.

Terdapat ketentuan bahwa setiap peralihan hak atau pendaftaran hak karena pewarisan wajib dilengkapi dengan surat bukti sebagai ahli waris, karena seorang ahli waris tidak dapat langsung secara otomatis dapat menguasai dan melakukan balik nama atas harta warisan yang menjadi haknya setelah meninggalnya pewaris, melainkan untuk melakukan tindakan hukum terhadap apa yang telah menjadi haknya tersebut harus dilengkapi dengan adanya surat keterangan waris (Purwaka, 1999: 3). Dengan adanya surat keterangan waris tersebut ahli waris dapat melakukan tindakan hukum terhadap harta peninggalan pewaris secara bersama-sama.

Bentuk formal surat bukti sebagai ahli waris saat ini ada tiga bentuk dan tiga institusi yang dapat membuat yang disesuaikan dengan golongan penduduk Warga Negara Indonesia (Adjie, 2008:17).

Sebagaimana terdapat dalam Pasal 163 Indische Staatsregeling dikutip dari aturan baru yang sudah mulai berlaku sejak 1 Januari 1920 dalam Pasal 109 Regerings Reglement (Hadisoeprapto,1988:48). Penduduk Indonesia dibagi kedalam tiga golongan yaitu:

1) Golongan Eropa,

2) Golongan Bumiputera,

3) Golongan Timur Asing.

Pembuatan bukti sebagai ahli waris dibuat berdasarkan golongan penduduk sesuai dengan ketentuan Pasal 111 ayat (1) huruf c angka 4 tentang Peraturan Menteri Negara Agraria/Kepala Kantor Pertanahan Nasional Nomor 3 tahun 1997 tentang Pelaksanaan Peraturan Pemerintah Nomor 24 Tahun 1997 tentang Pendaftaran Tanah, yaitu:

1) Bagi Warga Negara Indonesia penduduk asli: surat keterangan ahli waris yang dibuat oleh para ahli waris dengan disaksikan oleh dua orang saksi dan dikuatkan oleh Kepala Desa/ Kelurahan dan Camat tempat tinggal pewaris pada waktu meninggal dunia;

2) Bagi Warga Negara Indonesia keturunan Tionghoa: akta keterangan hak mewaris dari Notaris;

3) Bagi Warga Negara Indonesia keturunan Timur Asing lain, surat 
keterangan waris dari Balai Harta

Peninggalan.

Penduduk Indonesia yang beragama Islam, dalam mengeluarkan surat keterangan waris, pihak yang berwenang mengeluarkan penetapan mengenai Pembagian Harta Peninggalan orang yang beragama Islam yaitu Pengadilan Agama. Sebagaimana dengan yang diatur dalam Pasal 4 huruf b Undang-Undang Nomor 3 Tahun 2006 tentang perubahan atas Undang-Undang Nomor 7 Tahun 1989 tentang Peradilan Agama.

Dengan berlakunya Undang-Undang tentang Kewarganegaraan tersendiri yaitu Undang-Undang Nomor 12 Tahun 2006 Tentang Kewarganegaraan Republik Indonesia, tidak lagi mengatur mengenai penggolongan penduduk karena sesuai dengan Pasal 2 Undang-Undang Nomor 12 Tahun 2006 tentang Kewarganegaraan Republik Indonesia telah disebutkan bahwa "Yang menjadi Warga Negara Indonesia adalah orang-orang bangsa Indonesia asli dan orang-orang bangsa asing yang disahkan dengan undangundang sebagai warga negara". Serta ketentuan dalam Pasal 1 ayat (3) UndangUndang Nomor 24 Tahun 2013 tentang Perubahan atas Undang-Undang Nomor 23 tahun 2006 tentang Adiministrasi Kependudukan yakni "Warga Negara Indonesia adalah orang-orang bangsa
Indonesia asli dan orang-orang bangsa lain yang disahkan dengan Undang-Undang sebagai Warga Negara Indonesia. Sehingga dengan demikian seharusnya dalam hal pembuatan surat bukti sebagai ahli waris, Warga Negara Indonesia tidak lagi digolongkan berdasarkan golongan penduduk. Berkaitan itu, rumusan masalah penelitian ini sebagai berikut:

1) Mengapa masih ada penggolongan penduduk dalam pembuatan Surat Keterangan Waris terkait pendaftaran hak atas tanah setelah berlakunya Undang-Undang Nomor 12 Tahun 2006 Tentang Kewarganegaraan Republik Indonesia?

2) Bagaimana kekuatan hukum akta keterangan hak mewaris yang dibuat oleh Notaris, Surat Keterangan Ahli waris yang dibuat oleh ahli waris dan dikuatkan oleh Kepala Desa/Kelurahan dan Camat, dan Surat Keterangan Waris yang dibuat oleh Balai Harta Peninggalan terkait pendaftaran hak atas tanah setelah berlakunya Undang-Undang Nomor 12 Tahun $2006 \quad$ Tentang Kewarganegaraan Republik Indonesia?

Penelitian ini merupakan penelitian yang bersifat yuridis normatif. Yuridis normatif adalah jenis penelitian yang dalam mendekati suatu permasalahan 
digunakan asas-asas dan norma-norma hukum yang terkait.

\section{Metode Penelitian}

Penelitian ini menggunakan beberapa pendekatan yaitu pendekatan Perundangundangan (statute approach) yaitu digunakan untuk mengkaji dan menganalisis semua undang-undang dan pengaturan yang bersangkut paut dengan isu hukum, pendekatan historis (historical approach) digunakan untuk mengkaji latar belakang yang akan dipelajari, dan perkembangan pengaturan mengenai isu yang dihadapi, dan pendekatan konseptual (conceptual approach) yaitu beranjak dari pandangan-pandangan dan doktrin-doktrin yang berkembang didalam ilmu hukum (Marzuki, 2009:93). Adapun pengolahan data digunakan Interpretasi Gramatikal (menurut bahasa) dalam memaknai, menafsirkan kata-kata dalam undangundang sesuai dengan kaidah bahasa dan kaidah hukum tata bahasa (Hamidi, 2005: 53), dan Interpretasi Historis (sejarah) dalam memahami berbagai aturan perundang-undangan yang mengatur mengenai surat keterangan waris melalui sejarahnya.

\section{Hasil dan Pembahasan}

Penggolongan Penduduk Dalam Pembuatan Surat Keterangan Waris Terkait Pendaftaran Hak Atas Tanah Setelah Berlakunya Undang-Undang Nomor 12 Tahun 2006 Tentang Kewarganegaraan Republik Indonesia

Surat keterangan waris adalah surat yang dijadikan dasar adanya hak bagi pihak ahli waris untuk melakukan perbuatan hukum atas suatu warisan yang ditinggalkan pewaris. Dengan adanya surat keterangan waris maka ahli waris dapat melakukan tindakan hukum terhadap harta peninggalan pewaris secara bersama-sama, baik mengenai tindakan kepengurusan maupun tindakan kepemilikan atas warisan tersebut. Dalam hal ini adalah berupa barang-barang harta peninggalan pewaris berupa tanah yang apabila ingin dilakukan balik nama dapat mengajukan permohonan ke Kantor Pertanahan setempat yaitu dengan cara:

a) Melakukan pendaftaran peralihan hak (balik nama) untuk tanah yang sudah terdaftar (bersertipikat).

b) Melakukan permohonan hak baru (sertipikat) atas tanah yang belum terdaftar seperti misalnya tanah girik, tanah bekas hak barat, tanah Negara (Harun, 2010:32).

Surat keterangan waris yang dalam pembuatannya dibagi menjadi beberapa golongan penduduk ini hanya terkait mengenai pengurusan tanah dikarenakan 
dasar hukumnya berada pada peraturan mengenai pertanahan. Namun hal ini dijadikan dasar acuan untuk perbuatan apapun diluar tanah karena memang tidak ada aturan yang secara spesifik mengatur mengenai surat keterangan waris. Surat keterangan ahli waris juga memiliki fungsi bagi para ahli waris untuk menggadaikan atau menjaminkan barang-barang harta peninggalan pewaris tersebut kepada pihak lain atau kreditur, apabila ahli waris hendak meminjam uang atau mengajukan permohonan kredit. Di samping itu surat keterangan ahli waris juga berfungsi untuk mengalihkan barang-barang harta peninggalan pewaris tersebut kepada pihak lain, misalnya menjual, menghibahkan, melepaskan hak, melakukan pengikatan jual beli dihadapan notaris dan lain-lainnya yang sifatnya berupa suatu peralihan hak, dan juga merubah status kepemilikan bersama atas barang harta peninggalan pewaris menjadi milik dari masing-masing ahli waris dengan cara melakukan atau membuat akta pembagian dan pemisahan harta peninggalan pewaris dihadapan notaris (Rahmad, 2012:70). Surat keterangan ahli waris juga dapat berfungsi sebagai alat bukti bagi ahli waris untuk dapat mengambil atau menarik uang dari pewaris yang ada pada suatu bank atau asuransi, sekalipun bagi setiap bank atau lembaga (Hanum, 2016:7).
Setelah Indonesia merdeka, melalui Pasal II aturan Peralihan Undang-Undang Dasar 1945 yang berbunyi "segala badan negara dan peraturan yang ada masih langsung berlaku selama belum diadakan yang baru menurut Undang-Undang Dasar ini." Kemudian dipertegas kembali dalam Peraturan Nomor 2 Tahun 1945 yang menyatakan bawa "segala badan-badan Negara dan peraturan-peraturan yang berlaku sampai berdirinya Negara Republik Indonesia pada 17 Agustus 1945, selama belum diadakan yang baru menurut Undang-Undang Dasar ini masih berlaku asal tidak bertentangan dengan UndangUndang Dasar tersebut."

Untuk melaksanakan Peraturan Pemerintah Nomor 24 Tahun 1997 ini maka dibuat Peraturan Menteri Negara Agraria/ Kepala Badan Pertanahan Nasional Nomor 3 Tahun 1997 tentang Ketentuan Pelaksanaan Peraturan Pemerintah Nomor 24 Tahun 1997 tentang Pendaftaran Tanah. Dalam Pasal 42 Peraturan Pemerintah Nomor 24 Tahun 1997 memerintahkan adanya surat keterangan waris sebagai dasar peralihan hak karena pewarisan, yang pada intinya bahwa jika penerima waris hanya satu orang, maka pembuktian peralihan haknya adalah surat tanda bukti sebagai ahli waris. Pendaftaran peralihan haknya disertai dengan surat keterangan kematian pewaris 
dan sertifikat bagi tanah sudah pernah didaftar. Jika belum pernah didaftar maka surat bukti hak atau surat keterangan kepala desa/kelurahan yang menyatakan bahwa yang bersangkutan menguasai bidang tanah tersebut dan surat keterangan yang menyatakan bahwa bidang tanah yang bersangkutan belum bersertifikat dari Kantor Pertanahan. Akan tetapi jika penerima waris lebih dari satu orang, maka pembuktian peralihan haknya selain harus ada surat tanda bukti sebagai ahli waris harus ada akta pembagian warisan, namun apabila belum ada akta pembagian warisan dapat didaftar peralihan haknya sebagai hak bersama (Hamidah,.2012:335).

Pasal 111 ayat (1) huruf c angka 4 tentang Peraturan Menteri Negara Agraria/Kepala Badan Petanahan Nasional Nomor 3 Tahun 1997 tentang Pelaksanaan Peraturan Pemerintah Nomor 24 Tahun 1997 tentang Pendaftaran Tanah secara substansi adalah cacat dan tidak memenuhi tujuan hukum yakni keadilan, karena mengatur mengenai penggolongan penduduk yang sudah tidak relevan digunakan saat ini dan bertentangan dengan perundang-undangan lainnya.

Penggolongan penduduk dalam pembuatan surat keterangan waris terkait pendaftaran hak atas tanah setelah berlakunya Undang-Undang Nomor 12 Tahun 2006 tentang Kewarganegaraan Republik Indonesia masih ada karena merupakan politik hukum dari pemerintahan Kolonial Belanda, hukum yang berlaku saat ini pada dasarnya merupakan produk pemerintahan HindiaBelanda yang berlaku di Indonesia berdasarkan atas asas konkordansi, artinya bahwa hukum yang berlaku di Indonesia sama dengan ketentuan hukum yang berlaku di negeri Belanda. Keberlakuan ketentuan tersebut semata-mata untuk mengisi kekosongan hukum (rechtvacuum), serta berberdasarkan pada Pasal II aturan Peralihan Undang-Undang Dasar 1945 setelah amandemen ke-4 menjadi Pasal I disebutkan bahwa "segala badan-badan Negara dan peraturanperaturan yang berlaku sampai berdirinya Negara Republik Indonesia pada 17 Agustus 1945, selama belum diadakan yang baru menurut Undang-Undang Dasar ini masih berlaku asal tidak bertentangan dengan Undang-Undang Dasar tersebut." sehingga selama aturan mengenai penggolongan penduduk dalam pembuatan surat keterangan waris belum diganti, masyarakat akan tetap menggunakan ketentuan mengenai penggolongan penduduk jika tidak ada alternatif lain. 
Kekuatan Hukum Beberapa Akta Keterangan Hak Mewaris Terkait Pendaftaran Hak Atas Tanah Setelah Berlakunya Undang-Undang Nomor 12 Tahun 2006

Alat bukti yang sah atau diterima dalam suatu perkara (perdata), pada dasarnya terdiri dari ucapan dalam bentuk keterangan saksi-saksi, pengakuan, sumpah, dan tertulis dapat berupa tulisantulisan yang mempunyai nilai pembuktian.Dalam perkembangan alat bukti sekarang ini (untuk perkara pidana juga perkara perdata) telah diterima pula alat bukti elektronis atau yang terekam atau yang disimpan secara elektronis sebagai alat bukti yang sah dalam persidangan pengadilan (Adjie, 2008:47). Terdapat beberapa macam alat pembuktian yang ditentukan dalam Undang-Undang, yakni dalam Pasal 164 HIR, Pasal 284 RBg, dan Pasal 1866 KUHPerdata yang mana pada intinya adalah sebagai berikut (Adjie, 2008:47):

(i) Alat bukti dengan surat atau tertulis.

(ii) Alat bukti dengan saksi

(iii) Alat bukti persangkaanpersangkaan.

(iv) Alat bukti pengakuan.

(v) Alat bukti sumpah

Diterbitkannya surat keterangan waris berkaitan dengan fungsi surat sebagai alat bukti, dalam hal ini untuk membuktikan tentang subjek hukum atau siapa saja yang dapat disebut sebagai ahli waris atau adanya hubungan hukum antara seseorang dengan satu orang lainnya. Dalam konteks hukum perdata, termasuk hukum waris, bukti surat akan menjadi bukti yang penting dan paling utama dibandingkan dengan alat bukti yang lain, maka disini lebih difokuskan pada kekuatan hukum suatu alat bukti dalam bentuk tulisan.

Alat bukti berupa surat atau tulisan dapat berupa surat yang dibuat secara tertulis baik oleh para pihak yang berperkara secara dibawah tangan atau dibuat oleh pihak lain yang karena jabatannya mempunyai hak untuk itu. Alat bukti tulisan ada 3 (tiga) macam yaitu:

- Akta autentik ditentukan dalam Pasal 165 HIR, Pasal 285 RBg, dan Pasal 1868 KUHPerdata.

- Akta dibawah tangan ditentukan dalam Pasal 288 RBg jo. Pasal 1875 BW jo. Pasal 1b Ordonansi 1867 yang disisipkan dengan Stb. 1916 Nomor 43 dan 44

- Surat biasa ditentukan dalam Pasal 137 dan Pasal 138 HIR jo. Pasal 148 dan 149 Rv.jo. Pasal 289 dan 290 RBg. 
Berikut tabel mengenai keunggulan serta tulisan:

kelemahan dari alat bukti dalam bentuk

Tabel 1: Keunggulan dan Kelemahan Akta Autentik, Akta Bawah Tangan dan Surat Biasa

\begin{tabular}{|c|c|c|}
\hline & Keunggulan & Kelemahan \\
\hline Akta Otentik & $\begin{array}{l}\text { Akta Otentik sebagai alat bukti } \\
\text { yang sempurna yang dibuat oleh } \\
\text { pejabat yang berwenang. } \\
\text { Mempunyai kekuatan pembuktian: } \\
\text { a. Kekuatan pembuktian lahiriah } \\
\text { (Uitwendige Bewijskracht): } \\
\text { dimaksudkan kemampuan dari } \\
\text { akta itu sendiri untuk } \\
\text { membuktikan dirinya sebagai } \\
\text { akta autentik. } \\
\text { bekuatan pembuktian formal } \\
\text { (formele Berwijskracht): } \\
\text { sepanjang mengenai akta } \\
\text { pejabat, akta itu membuktikan } \\
\text { kebenaran dari apa yang } \\
\text { disaksikan, yang dilihat, } \\
\text { didengar dan juga dilakukan } \\
\text { sendiri oleh notaris sebagai } \\
\text { pejabat umum didalam } \\
\text { menjalankan jabatannya. } \\
\text { Kekuatan pembuktian materiil } \\
\text { (materiele Bewijskracht) : akta } \\
\text { itu dianggap dibuktikan sebagai } \\
\text { yang benar terhadap setiap } \\
\text { orang, yang menyuruh } \\
\text { adakan/buatkan akta itu sebagai } \\
\text { tanda bukti terhadapp dirinya, } \\
\text { akta itu mempunyai kekuatan } \\
\text { pembuktian materiil. }\end{array}$ & - \\
\hline $\begin{array}{l}\text { Akta di Bawah } \\
\text { Tangan }\end{array}$ & $\begin{array}{l}\text { - Bentuknya bebas } \\
\text { - Pembuatannya tidak harus di } \\
\text { hadapan pejabat umum yang } \\
\text { berwenang }\end{array}$ & $\begin{array}{l}\text { 1. Akta dibawah tangan } \\
\text { yang diakui dalam } \\
\text { kekuatan pembuktian } \\
\text { hampir sama dengan } \\
\text { akta autentik. } \\
\text { Bedanya pada } \\
\text { kekuatan bukti keluar, } \\
\text { yang tidak dimiliki } \\
\text { oleh akta dibawah } \\
\text { tangan. } \\
\text { 2. Apabila tanda tangan } \\
\text { didalam akta dibantah } \\
\text { kebenarannya maka } \\
\text { lawan pembantah } \\
\text { tersebut yang harus } \\
\text { membuktikan }\end{array}$ \\
\hline
\end{tabular}




\begin{tabular}{|c|c|c|}
\hline & & $\begin{array}{l}\text { kebenarannya. Hal ini } \\
\text { berbeda dengan akta } \\
\text { autentik justru yang } \\
\text { membantah yang } \\
\text { harus membuktikan } \\
\text { ketidakbenarannya. }\end{array}$ \\
\hline & $\begin{array}{l}\text { - Akta dibawah tangan yang } \\
\text { dilegalisasi: notaris hanya } \\
\text { menjamin kepastian tanggal } \\
\text { penanda tanganan, tanpa } \\
\text { bertanggung jawab mengenai isi } \\
\text { akta. } \\
\text { - Akta dibawah tangan yang di } \\
\text { waarmerking, notaris hanya } \\
\text { menjamin telah terjadinya } \\
\text { pendaftaran akta pada tanggal } \\
\text { yang tertera pada surat. }\end{array}$ & - \\
\hline Surat Biasa & $\begin{array}{l}\text { Mempunyai kekuatan pembuktian } \\
\text { mutlak dan pasti karena surat } \\
\text { tersebut secara yuridis kebenaran } \\
\text { dan keabsahannya tidak dapat } \\
\text { disangkal oleh pihak lawan. }\end{array}$ & - \\
\hline
\end{tabular}

Sumber: Data Primer, diolah, 2017

Kekuatan hukum akta keterangan hak mewaris yang dibuat oleh notaris, surat keterangan ahli waris yang dibuat oleh ahli waris dan dikuatkan oleh Kepala Desa/Lurah dan camat, dan surat keterangan waris yang dibuat oleh Balai Harta Peninggalan, jika dianalisis maka akan diperoleh hasil sebagai berikut.

\section{1) Kekuatan hukum akta keterangan hak mewaris yang dibuat oleh Notaris}

Untuk menguji apakah akta keterangan hak mewaris yang dibuat oleh notaris, maka harus diukur berdasarkan ketentuan mengenai akta otentik. Menurut Iwan Soerodjo, terdapat tiga unsur esensialia agar terpenuhinya syarat formal suatu akta otentik, yaitu dibuat dalam bentuk ditentukan oleh Undang-Undang, dibuat oleh atau dihadapan pejabat umum yang berwenang, dan akta yang dibuat oleh atau dihadapan pejabat umum yang berwenang untuk itu dan tempat dimana akta tersebut dibuat (Soerodjo, 2003:148).

Sebagaimana diatur dalam Pasal 1868 KUHPerdata yang menentukan bahwa "suatu akta otentik ialah suatu akta yang ditentukan oleh Undang-Undang, dibuat oleh atau dihadapan pejabat umum yang berkuasa untuk itu ditempat dimana akta itu dibuat." Dari ketentuan Pasal 1868 KUHPerdata tersebut suatu akta dapat 
dikatakan sebagai akta otentik apabila memenuhi syarat sebagai berikut:

1) Akta tersebut dibuat oleh (door) atau dibuat dihadapan (ten overstaan), seorang pejabat umum (openbare ambtenaren).

2) Akta tersebut harus dibuat dalam bentuk (vorm) yang telah ditentukan oleh Undang-Undang (wettelikje vorm).

3) Pejabat umum yang membuat akta harus mempunyai kewenangan untuk membuat akta tersebut, baik kewenangan berdasarkan daerah/wilayah kerjanya atau waktu pada saat akta tersebut dibuat.

Akta otentik menurut F.Eka Sumarningsih dibagi menjadi dua yaitu partij acta dan relaas acta (Sumarningsih,2001:7). Akta partij atau akta pihak adalah akta yang dibuat dihadapan notaris, artinya akta yang dibuat berdasarkan keterangan atau perbuatan pihak yang menghadap notaris, dan keterangan atau perbuatan itu agar dikonstatier oleh notaris untuk dibuatkan akta. Sedangkan akta relaas atau akta pejabat adalah akta yang dibuat oleh notaris sebagai pejabat umum yang memuat uraian secara otentik tentang semua peristiwa atau kejadian yang dilihat, dialami, dan disaksikan oleh notaris sendiri.
Pemberian kualifikasi Notaris sebagai pejabat umum berkaitan dengan wewenang notaris. Menurut Pasal 15 ayat (1) Undang-Undang Nomor 2 Tahun 2014 tentang Perubahan Atas Undang-Undang Nomor 30 Tahun 2004 tentang Peraturan Jabatan Notaris bahwa notaris berwenang membuat akta otentik, sepanjang pembuatan akta-akta tersebut tidak ditugaskan atau dikecualikan kepada pejabat atau orang lain.

Dengan demikian Pejabat umum merupakan suatu jabatan yang disandang atau diberikan kepada mereka yang diberi wewenang oleh aturan hukum dalam pembuatan akta otentik, dan notaris sebagai pejabat umum kepadanya diberikan kewenangan untuk membuat akta otentik. Sehingga dalam hal ini memenuhi syarat yang ditentukan oleh Pasal 1868 KUHPerdata.

Kedua, bentuk (vorm) akta yang dibuat oleh pejabat umum agar dikatakan sebagai akta otentik, harus ditentukan oleh Undang-Undang. Bentuk akta keterangan hak mewaris yang dibuat oleh notaris hanya diatur dalam Pasal 111 ayat (1) huruf c angka 4 Peraturan Menteri Negara Agraria/Kepala Badan Pertanahan Nasional Nomor 3 Tahun 1997 tentang Ketentuan Pelaksanaan Peraturan Pemerintah Nomor 24 Tahun 1997 tentang Pendaftaran Tanah. Dari pasal tersebut dapat dilihat bahwa notaris berwenang 
untuk membuat surat keterangan waris dalam bentuk akta keterangan waris.

Pendapat lain yang menyarankan agar

Habib Adjie menyarankan agar notaris membuat akta keterangan waris dalam bentuk akta pihak (partij acta), sesuai dengan wewenang yang dimiliki oleh notaris, yaitu untuk membuat akta otentik berdasarkan Pasal 15 ayat (1), Pasal 38 dan Pasal 58 ayat (2) Undang-Undang Nomor 2 Tahun 2014 tentang Perubahan Atas Undang-Undang Nomor 30 Tahun 2004 tentang Jabatan Notaris serta Pasal 1868 KUHPerdata yaitu dengan membuat Akta Keterangan sebagai ahli waris dalam bentuk akta pihak, karena:

a) Notaris hanya menuliskan pernyataan kehendak atau keinginan para pihak, agar susunan ahli warisnya dibuat dengan akta otentik;

b) Tidak diperlukan campur tangan pemerintah untuk membuat pembuktian susunan sebagai ahli waris, hal tersebut merupakan hak warga negara.

c) Tidak ada pertanggungjawaban dari pemerintah, jika ada penyimpangan dalam penyusunan ahli waris, tapi hal tersebut semata-mata tanggung jawab yang bersangkutan;

d) Menghargai hak pribadi tiap warga negara, bahwa hanya yang bersangkutanlah yang mengetahui siapa-siapa saja ahli warisnya. notaris tidak membuat surat keterangan waris dalam bentuk akta pihak (partij $a c t a)$, karena apabila dibuat dalam bentuk akta pihak dirasa tidak sesuai karena dalam akta pihak terdapat kehendak dari para pihak yang dituangkan dalam isi akta, mengingat dalam surat keterangan waris terdapat pembagian harta waris yang dibuat oleh notaris berdasarkan pengetahuannya mengenai hukum waris. Maka dirasa tidaklah sesuai apabila dalam isi akta pihak terdapat pembagian harta waris yang dibuat oleh notaris.

Tan Thong Kie berpendapat, bahwa apabila surat keterangan waris dibuat dalam bentuk akta dibawah tangan maka "siapakah para penghadap dan apakah akta tersebut dibuat menurut Undang-Undang Nomor 30 Tahun 2004 tentang Peraturan Jabatan Notaris (PJN). Kalau demikian, harus ada (para) penghadap, semua angka harus ditulis dengan huruf, semua pengubahan harus diparaf, dan sebagainya...."(Kie, 2007:567).

Tan Tong Kie juga tidak menyalahkan apabila surat keterangan waris dibuat dalam bentuk akta notaris

Dibuatnya akta keterangan hak mewaris dalam suatu bentuk akta yang ditetapkan oleh Undang-Undang sangatlah berpengaruh besar terhadap keotentikan 
akta notaris, karena berdasarkan Pasal 1868 KUHPerdata keotentikan suatu akta apabila bentuknya ditetapkan oleh Undang-Undang. Sesuai dengan ketentuan dalam Pasal 38 ayat (1) Undang-Undang Nomor 2 Tahun 2014 tentang Perubahan Atas Undang-Undang Nomor 30 Tahun 2004 tentang Jabatan Notaris yang menyebutkan bahwa setiap Akta terdiri atas awal Akta atau kepala akta, badan akta, dan akhir atau penutup akta. Sehingga akta keterangan hak waris yang dibuat oleh notaris termasuk kedalam akta otentik.

Ketiga, pejabat umum yang membuat akta harus mempunyai kewenangan untuk membuat akta tersebut, baik kewenangan berdasarkan daerah/wilayah kerjanya atau waktu pada saat akta tersebut dibuat. Wewenang notaris meliputi empat hal, yaitu (Tobing,1983:49). Notaris harus berwenang sepanjang yang menyangkut akta yang harus dibuatnya. Wewenang notaris dalam pembuatan akta otentik sepanjang tidak dikecualikan kepada pihak atau pejabat lain, atau notaris juga berwenang membuatnya disamping dapat dibuat oleh pihak atau pejabat lain, mengandung makna bahwa wewenang notaris dalam membuat akta otentik mempunyai wewenang yang umum, sedangkan pihak lain mempunyai wewenang yang terbatas.
Suatu akta yang dibuat oleh pejabat tanpa ada wewenang dan tanpa ada kemampuan untuk membuatnya atau tidak memenuhi syarat, maka tidaklah dianggap sebagai akta otentik, tetapi hanya mempunyai kekuatan sebagai akta dibawah tangan apabila ditandatangani oleh pihak-pihak yang bersangkutan (Mertokusumo,1993:124).

Pasal 15 Undang-Undang Nomor 2 Tahun 2014 tentang Perubahan Atas Undang-Undang Nomor 30 Tahun 2004 tentang Jabatan Notaris menentukan wewenang notaris. Kewenangan notaris yaitu:

(1) Notaris berwenang membuat Akta autentik mengenai semua perbuatan, perjanjian dan penetapan yang diharuskan oleh peraturan perundangundangan dan/atau yang dikehendaki oleh yang berkepentingan untuk dinyatakan dalam Akta autentik, menjamin kepastian tanggal pembuatan akta, menyimpan akta, memberikan grosse, salinan dan kutipan Akta, semua itu sepanjang pembuatan akta itu tidak juga ditugaskan atau dikecualikan kepada pejabat lain atau orang lain yang ditetapkan oleh undang-undang.

(2) Notaris berwenang pula:

a) Mengesahkan tanda tangan dan menetapkan kepastian tanggal surat 
dibawah tangan dengan endaftar dalam buku khusus;

b) Membukukan surat-surat bawah tangan dengan mendaftar dalam buku khusus;

c) Membuat kopi dari asli surat-surat dibawah tangan berupa salinan yang memuat uraian sebagaimana ditulis dan digambarkan dalam surat yang bersangkutan;

d) Melakukan pengesahan kecocokan fotocopi dengan surat aslinya;

e) Memberikan penyuluhan hukum sehubungan dengan pembuatan akta;

f) Membuat akta yang berkaiatan dengan pertanahan; atau

g) Membuat akta risalah lelang.

(4) Selain kewenangan sebagaimana dimaksud pada ayat (1) dan ayat (2), Notaris mempunyai kewenangan lain yang diatur dalam perundangundangan.

Berdasarkan ketentuan diatas dapat diketahui bahwa wewenang ini merupakan suatu batasan, bahwa notaris tidak boleh melakukan suatu tindakan diluar wewenang tersebut. Sebagai contoh dalam pembuatan surat keterangan waris memang sama sekali tidak disebutkan notaris berwenang membuat akta keterangan hak mewaris, namun kewenangan notaris membuat akta keterangan hak mewaris hanya berdasarkan Pasal 111 ayat (1) huruf c angka 4 Peraturan Menteri Negara Agraria/Kepala Badan Pertanahan Nasional Nomor 3 Tahun 1997 tentang Ketentuan Pelaksanaan Peraturan Pemerintah Nomor 24 Tahun 1997 tentang Pendaftaran Tanah.

Dengan demikian, maka akta keterangan hak mewaris yang dibuat oleh notaris merupakan akta otentik yang berdasarkan Pasal 1868 KUHPerdata, dari segi pembuktian akta keterangan waris dalam bentuk akta otentik mempunyai nilai pembuktian yang sempurna karena dibuat dihadapan pejabat yang berwenang Notaris (Yuriz, 2016;10). Akta otentik memberikan suatu bukti yang sempurna tentang apa yang termuat di dalamnya, sejauh akta autentik masih dapat dipakai, dan kesepakatan yang terdapat didalamnya belum berakhir, maka sekalipun para pihak telah meninggal, para ahli warisnya tetap harus dan wajib mematuhi segala ketentuan yang tertuang di dalam akta tersebut. Keunggulan keterangan ahli waris dalam bentuk akta otentik, jika isinya akan diperbaiki, maka akta keterangan ahli waris yang sebelumnya harus dicabut oleh mereka yang membuatnya dan kemudian dibuat akta baru sesuai fakta yang sebenarnya yang dinginkan oleh para pihak. 
2) Kekuatan hukum surat keterangan ahli waris yang dibuat oleh ahli waris dan dikuatkan oleh kepala desa/kelurahan dan camat

Surat keterangan waris yang dibuat oleh ahli waris berfungsi sebagai suatu instrument yang dapat membuktikan apakah seseorang adalah benar-benar ahli waris dari pewaris. Sesuai dengan ketentuan Pasal 111 ayat (1) huruf c angka 4 Peraturan Menteri Negara Agraria/Kepala Badan Pertanahan Nasional Nomor 3 Tahun 1997 tentang Ketentuan Pelaksanaan Peraturan Pemerintah Nomor 24 Tahun 1997 tentang Pendaftaran Tanah, pembuktian sebagai ahli waris untuk golongan pribumi dibuat oleh ahli waris sendiri, disaksikan oleh dua orang saksi dan dikuatkan oleh Kepala Desa/Lurah dan Camat setempat sesuai dengan tempat tinggal terakhir pewaris, meskipun dalam hal ini surat keterangan ahli waris dibuat sendiri oleh ahli waris yang merupakan hak perdata dari ahli waris, namun Kepala Desa/Lurah dan Camat juga memiliki peran serta dalam menguatkan surat keterangan ahli waris tersebut. Menguatkan dalam hal ini berarti menambah unsur kekuatan terhadap surat keterangan ahli waris sebagai suatu alat bukti perdata. Kehadiran ataupun kesaksian seorang pejabat umum terhadap suatu alat bukti dapat menambah kekuatan pembuktiannya hal ini dikategorikan kedalam unsur formal suatu akta.
Formalitas suatu akta yaitu mengenai kebenaran apa yang dilihat, disaksikan dan didengar oleh seorang pejabat, juga mengenai kebenaran pernyataan ataupun keterangan para pihak yang disampaikan dihadapan pejabat yang berwenang.

Peran serta Kepala Desa/Lurah dan Camat dalam menguatkan surat keterangan ahli waris menimbulkan permasalah yaitu apakah Kepala Desa/Lurah dan Camat berwenang menguatkan surat keterangan ahli waris yang merupakan bukti perdata. Ditinjau dari Pasal 126 ayat 2 dan 3, Pasal 127 ayat 2 dan ayat 3, Pasal 206 dan Pasal 207 Undang-undang Nomor 32 Tahun 2004 tentang Pemerintahan Daerah. Maka berdasarkan uraian diatas Camat, Lurah dan Desa tidak berwenang untuk menguatkan surat keterangan ahli waris karena Camat, Lurah dan Desa berada dalam ruang lingkup Hukum Administrasi (Negara) dengan posisi sebagai Badan atau Pejabat Tata Usaha Negara yang melaksanakan wewenang pemerintahan. Oleh karena itu sangat rancu apabila surat keterangan ahli waris yang berada dalam ruang lingkup hukum perdata harus dikuatkan oleh Badan atau Pejabat Tata Usaha Negara.

Dengan demikian, maka surat keterangan ahli waris yang dibuat oleh ahli waris merupakan akta dibawah tangan, mempunyai kekuatan pembuktian sepanjang para pihak mengakuinya atau 
tidak ada penyangkalan dari salah satu pihak, jika para pihak mengakuinya, maka akta di bawah tangan tersebut mempunyai kekuatan pembuktian yang sempurna sebagaimana akta otentik, jika salah satu pihak tidak mengakuinya, beban pembuktian diserahkan kepada pihak yang menyangkal akta tersebut, dan penilaian penyangkalan atas bukti tersebut diserahkan kepada hakim.

\section{3) Kekuatan hukum surat keterangan waris yang dibuat oleh balai harta peninggalan}

Pembuatan surat keterangan waris untuk golongan Timur asing yaitu dibuat oleh Balai Harta Peninggalan berdasarkan pada ayat 1, Pasal 14 dari Instruksi Voor de Gouvernement Landmeters (Stbl. 1916 No.517) (Adjie, 2008:22) sebagaimana diuraikan bahwa membuktikan eseorang ahli waris dari siapa merupakan hak perdata seluruh manusia.

Balai Harta Peninggalan merupakan bagian dari struktur organisasi Dapartemen Hukum dan Hak Asasi Manusia, dibawah lingkungan Direktorat Perdata. Secara struktural maka Balai Harta Peninggalan merupakan lembaga pemerintahan (eksekutif) yang melaksanakan urusan pemerintah. Lembaga yang berada dalam ruang lingkup eksekutif atau pemerintah yang melaksanakan urusan pemerintah dikategorikan sebagai Pejabat Tata Usaha
Negara (Pasal 1 angka 2 Undang-Undang Nomor 5 Tahun 1986 tentang Peradilan Tata Usaha Negara) sebagai Badan Tata Usaha Negara diberikan wewenang untuk mengeluarkan surat keputusan atau penetapan yang bersifat konkret, individual, dan final (Pasal 1 ayat (3) Undang-Undang Nomor 5 Tahun 1986 tentang Peradilan Tata Usaha Negara).

Surat keterangan waris merupakan suatu alat bukti dalam ranah bidang hukum perdata. Hal ini menjadi suatu ketidak jelasan apabila surat keterangan waris yang dikeluarkan oleh Balai Harta Peninggalan diperuntukkan bagi golongan Timur Asing lainnya menimbulkan suatu permasalahan, kemanakah surat keterangan waris yang merupakan penetapan dari Balai Harta Peninggalan ini harus dipermasalahkan atau dibatalkan. Apakah ke lingkungan peradilan tata usaha negara karena merupakan penetapan tertulis yang dikeluarkan oleh badan atau pejabat tata usaha negara, atau kedalam lingkungan peradilan umum karena merupakan suatu alat bukti dalam ranah bidang hukum perdata. Surat keterangan waris seperti ini memiliki kekuatan hukum tetap, namun masih dibisa diajukan gugatan apabila terdapat permasalahan dalam pembuatan surat keterangan waris tersebut. 
Dengan demikian, Pasal 111 ayat (1) huruf c angka 4 Peraturan Menteri Negara Agraria/Kepala Badan Pertanahan Nasional Nomor 3 Tahun 1997 tentang Ketentuan Pelaksanaan Peraturan Pemerintah Nomor 24 Tahun 1997 tentang Pendaftaran Tanah bisa dikatakan belum memberikan kepastian hukum, karena pada dasarnya akta keterangan hak mewaris yang dibuat oleh Notaris, surat keterangan ahli waris yang dibuat sendiri oleh ahli waris dan dikuatkan oleh Camat dan Lurah/Kepala Desa, serta surat keterangan waris yang dibuat oleh Balai Harta Peninggalan, memiliki kekuatan hukum yang bermacam-macam sesuai dengan bentuknya.

Dari ketiga institusi kelembagaan yang diberikan wewenang untuk membuat bukti sebagai ahli waris bahwa notarislah yang paling tepat untuk membuat bukti sebagai ahli waris. Notaris sebagai sebuah jabatan, dimana seluruh jabatan yang ada di negeri ini mempunyai wewenang dan aturan hukumnya tersendri sebagai batasan agar jabatan dapat berjalan dengan baik dan tidak bertabrakan dengan wewenang jabatan lainnya. Setiap wewenang harus ada dasar hukumnya, sehingga wewenang pejabat apapun harus jelas dan tegas dalam peraturan perundang-undangan yang mengatur pejabat atau jabatan tersebut. selain itu pembuktian dengan akta otentik yang dibuat oleh notaris mempunyai kelebihan yaitu memiliki kekuatan pembuktian yang sempurna. Akta otentik merupakan bukti yang tidak dapat disangkal lagi, kecuali pihak lawan mengajukan bukti lain yang menyatakan sebaliknya. Selain itu, isinya dapat dipertanggungjawabkan karena merupakan akta otentik. Dengan berbentuk akta otentik, maka dasar hukum notaris membuatnya sebagai dasar kewenangan jelas dan sesuai dengan kepastian hukum. Dengan dibuat oleh notaris, maka akan dilakukan pengecekan ke daftar Pusat Wasiat (DPW).

\section{Simpulan}

1) Penggolongan penduduk dalam pembuatan surat keterangan waris terkait pendaftaran hak atas tanah setelah berlakunya Undang-Undang Nomor 12 Tahun 2006 tentang Kewarganegaraan Republik Indonesia masih terjadi karena merupakan politik hukum dari pemerintahan Kolonial Belanda, hukum yang berlaku saat ini pada dasarnya merupakan produk pemerintahan Hindia-Belanda yang berlaku di Indonesia berdasarkan atas asas konkordansi, keberlakuan ketentuan tersebut semata-mata untuk mengisi kekosongan hukum (rechtvacuum).

2) Surat Keterangan Waris yang dibuat berdasarkan golongan penduduk 
memiliki kekuatan hukum yang bermacam-macam sesuai dengan bentuknya. Dari ketiga institusi yang diberikan wewenang untuk membuat surat keterangan waris dapat dilihat bahwa notaris yang paling tepat, karena akta otentik yang dibuat oleh notaris memiliki kekuatan pembuktian yang sempurna.

\section{Daftar Pustaka}

\section{Buku}

Adjie, Habib, 2008, Sanksi Perdata dan Administratif Terhadap Notaris Sebagai Pejabat Publik. Bandung: Refika Aditama

Kie, Tan Tong, 2007, Studi Notariat \& Serba-Serbi Praktek Notaris, Jakarta: Ichtiar Baru van Hoeve

Harun, Arsyad, 2010, Tinjauan Yuridis Surat Keterangan Hak Waris bagi Penduduk di Indonesia.Bandung : Refika Aditama

Hamidi, Jazim, 2005, Hermeneutika Hukum. Yogjakarta: UII Press

Hujbers, Theo, 1995, Filsafat Hukum. Jakarta: Kanisius

Mertokusumo, Sudikno, 1993, Hukum Acara Perdata Indonesia. Yogyakarta: Liberty

Rahmad, Oesman Ali, 2012, Perbedaan Surat Keterangan Hak Waris dan Akta Keterangan Hak Waris. Bandung: Remaja Rosdakarya

Soerodjo, Irawan, 2003, Kepastian Hukum Hak Atas Tanah di Indonesia. Surabaya: Arloka
Tobing, G.H.S.Lumban, 1983 Peraturan Jabatan Notaris. Jakarta: Erlangga

Thamrin, Husni, 2011, Pembuatan Akta Pertanahan Oleh Notaris. Yogyakarta: Laksbang

\section{Jurnal}

Hanum, Latifah, 2016, "Kekuatan Hukum Surat Keterangan Ahli Waris Yang Dikeluarkan Kepala Desa Sebagai Alas Hak Dalam Pembuatan Akta Pengikatan Jual Beli (PJB) Oleh Notaris Bagi WNI Bumiputera", Premise Law Jurnal, Vol. 7, diakses 1 April 2017, doi: http://202.0.107.5/index.php/premise /article/view/15636/6586.

Hamidah, Upik, 2012, "Pembaharuan Standar Prosedure Operasi Pengaturan (SOP) Pelayanan Pendaftaran Peralihan Hak Milik Atas Tanah Karena Hibah Wasiat Berdasarkan Alat Bukti Peralihan Hak", Fiat Justitia Jurnal Ilmu Hukum, Vol. 6 No. 2(Mei-Agustus): 335, diakses 1 April 2017, doi: http://jurnal.fh.unila.ac.id/index.php/ fiat/article/view/79/80.

Yuriz, Okri Junanda, 2016, “Analisa Hukum Atas Perbedaan Bentuk Keterangan Waris Yang Dibuat Dalam Praktek Notaris Di Kota Medan”, Premise Law Jurnal, Vol. 13, diakses 1 April 2017, doi: http://jurnal.usu.ac.id/index.php/pre mise/article/view/16209/6910.

\section{Makalah}

Purwaka, I Gede.,1999,Keterangan Hak Mewaris Yang dibuat Oleh Notaris Berdasarkan Ketentuan Kitab Undang-Undang Hukum Perdata (Burgerljik wetboek).Program Spesialis Notariat dan Pertanahan Fakultas Hukum Universitas Indonesia 
Sumarningsih, F.Eka, 2001, Peraturan Jabatan Notaris.Diktat Kuliah, Program Studi Magister Kenotariatan, Fakultas Hukum Universitas Diponogoro, Semarang

\section{Peraturan Perundang-undangan}

Undang-Undang Dasar Negara Republik Indonesia Tahun 1995.

Kitab Undang-Undang Hukum Perdata (KUHPerdata).

Undang-Undang Nomor 2 Tahun 2014 tentang perubahan atas UndangUndang Nomor 30 Tahun 2004 tentang Jabatan Notaris

Undang-Undang Nomor 40 Tahun 2008 tentang Penghapusan Diskriminasi Rasial dan Etnis

Undang-Undang Nomor 3 Tahun 2006 tentang Perubahan atas UndangUndang Nomor 7 tahun 1989 tentangPengadilan Agama

Undang-Undang Nomor 12 Tahun 2006 tentang Kewarganegaraan Republik Indonesia

Undang-Undang Nomor 23 Tahun 2006 tentang Administrasi Kependudukan

Undang-Undang Nomor 32 Tahun 2004 tentang Pemerintahan Daerah

Undang-Undang Nomor 5 Tahun 1960 tentang Peraturan Dasar PokokPokok Agraria

Peraturan Pemeritah Nomor 10 Tahun 1961 tentang Pendaftaran Tanah

Peraturan Menteri Negara Agraria Nomor 3 Tahun 1997 tentang Ketentuan Pelaksanaan Peraturan Pemerintah Nomor $24 \quad$ Tahun 1997 tentangPendaftaran Tanah 